\title{
Best practice approach to the risk management of Legionella infection in health care facilities
}

\author{
B Casini ${ }^{1,2^{*}}$, A Buzzigoli ${ }^{1}$, P Valentini ${ }^{1,2}$, A Vecchione ${ }^{1}$, F Torracca ${ }^{1}$, A Baggiani ${ }^{1,2}$, G Privitera ${ }^{1,2}$ \\ From International Conference on Prevention \& Infection Control (ICPIC 2011) \\ Geneva, Switzerland. 29 June - 2 July 2011
}

\section{Introduction / objectives}

Aim of this study is to summarize and re-evaluate our eight year experience in the application of a water safety plan (WSP) in a 1500-bed teaching hospital.

\section{Methods}

WSP is based on a strategy integrating surveillance, maintenance, continuous chlorine-based disinfection and end-point filtration in critical areas. The strategy includes also molecular typing of the isolates and virulence genes expression analysis to detect the occurrence of adaptative changes in strains colonizing the water system.Recently, monochloramine treatment was applied in selected areas.

\section{Results}

Before the disinfection-filtration strategy, Legionella was isolated in $67 \%$ of samples (54/81), $79 \%$ of these samples exceeding $10^{3} \mathrm{CFU} / \mathrm{L}$. After eight-years of integrated strategy, Legionella was still present but the positive supply points were reduced to $22 \%(54 / 241)$ in the last year, and the samples exceeding $10^{3} \mathrm{CFU} / \mathrm{L}$ were cut down to $18 \%$. All isolates were identified as L. pneumophila sg1, two predominant and persisting clones, one of which showing increased chlorine tolerance. Longtime exposure to chlorine enhanced the ability to express more promptly some virulence genes involved in intracellular protozoa infection. The application of end-point filtration in high-risk areas is therefore required until a new effective disinfectant is introduced. Following the substitutions of chlorine dioxide by monochloramine, eradication of planktonic Legionella was observed although long-time effects have to be evaluated.

${ }^{1}$ Dep. Esperimental Pathology, MBIE, University of Pisa, Pisa, Italy Full list of author information is available at the end of the article

\section{Conclusion}

Standard environmental surveillance methods may not be sufficient to determine the most effective disinfection method and should be accompanied by evaluation of the susceptibility to sanitising agents.

\section{Disclosure of interest}

None declared.

\section{Author details}

${ }^{1}$ Dep. Esperimental Pathology, MBIE, University of Pisa, Pisa, Italy. ${ }^{2}$ U.O. Igiene ed Epidemiologia, Azienda Ospedaliero-Universitaria Pisana, Pisa, Italy.

Published: 29 June 2011

\section{doi:10.1186/1753-6561-5-S6-P305}

Cite this article as: Casini et al:: Best practice approach to the risk management of Legionella infection in health care facilities. BMC Proceedings 2011 5(Suppl 6):P305.

Submit your next manuscript to BioMed Central and take full advantage of:

- Convenient online submission

- Thorough peer review

- No space constraints or color figure charges

- Immediate publication on acceptance

- Inclusion in PubMed, CAS, Scopus and Google Scholar

- Research which is freely available for redistribution 